\title{
What Professional Librarians Expect from Administrators: One Librarian's View
}

\author{
Cheryl A. Price
}

There are thirteen qualities or job-related factors that librarians should expect to find in a position. These qualities must be provided by administrators for the best possible employeeemployer relationship. Although the qualities may seem to be idealistic, they are milestones that librarians should pursue. The qualities are stability, responsibility, job description, meaning in the position, leadership, flexibility, support by administration, clear administrative lines, prestige, professional salary, support services, growth opportunities, and a healthful and comfortable environment.

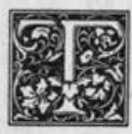

here are a number of job-related factors expected by librarians in a position. The factors may seem to be the descriptors of what an ideal administrator should provide his or her subordinate. However, it is not only important that librarians respond to the requirements of positions but that administrators recognize their responsibilities to their subordinates, which necessitate the provision of certain elements or job-related factors for a positive employee-employer relationship. For the purposes of this article, administrator is defined as an individual who directs or manages a division of a library. In the academic sphere this will include directors, associate directors, and assistant directors.

One of the first requirements of an able administrator is the provision of a stable environment for the employee under his or her jurisdiction. Most professionals do not expect the administration to shelter them from all unpleasantness; however, they do expect an environment where role ambiguity and work-related stress are kept to manageable proportions. Betsy Ann Stead and Richard W. Scannel sum- marized studies on role ambiguity, role conflict, and role clarity and noted that these factors were significantly related to job satisfaction. ${ }^{1}$ It is the obligation of the administrator to clarify the role a subordinate is expected to play not just by a job description but by actions and communications as well. There have been many instances in which a fine job description was utterly destroyed by the inconsistent administrator. This leaves the professional librarian wondering where he or she stands. Some administrators tend to ignore employees' job satisfaction because it is not an easily quantifiable dimension of employment. ${ }^{2}$ (The concept of management by objectives draws on the Maslow and Herzberg theories of human behavior. Herzberg identified motivation as being dependent upon a challenging job with an opportunity for achievement, recognition, responsibility, and growth. However, there are other theories regarding motivation and job satisfaction that may be more pertinent than Herzberg's theory.) Yet the wise administrator realizes that when people enjoy their roles in an organization, productivity increases.

Cheryl A. Price is Reference/Bibliographic Instruction Coordinator at the Illinois Institute of Technology, Chicago, Illinois 60616. 
Secondly, an administrator has the obligation to the staff and to him-or herself to match qualified people with appropriate positions. Alan L. Frohman has stated that a professional's primary motivator is his or her work. ${ }^{3}$ If this is the case, then if a professional's skills are matched by his or her interests, this will give added meaning to the work and will enhance the quality of the work. The person will feel good about coming in each day, where work will not be drudgery but will be satisfying. If a professional has interests in areas where he or she does not have skills, it may behoove the administrator to provide an opportunity for that growth, which is the third requirement of an able administrator.

Frohman points out that although job descriptions, performance measurement schemes, and the reward system are useful for heavily technical problem-solving and management decision-making tasks, it is equally important to develop inspiration, risk-taking, commitment, helpfulness, or curiosity. ${ }^{4}$ He notes that these socalled peripheral fields are areas where energy for innovative breakthroughs and solutions emerge. ${ }^{5}$ A professional librarian should expect to be encouraged rather than held back in these areas. What Frohmaan is alluding to as important for creative development is an environment that encourages trust in one's colleagues and superiors.

If a librarian is to obtain stability, meaning, responsibility, and growth from a position, it is also incumbent that the administrator provide a purpose-goals or objectives-for the library and its personnel. Each librarian needs to know where he or she fits in the objectives of the administration. Although job descriptions are a mandatory requirement for professionals, there should be flexibility within those job descriptions, which exist for the protection of both librarian and administrator. They are there to provide a sense of purpose and to place the librarian in the full spectrum of the library setting. The job description should be reviewed annually and be changed if necessary by mutual consent of administrators and librarians.

The administrator is obligated to provide the librarian with clear administrative lines so that there is no question regarding who has responsibility for what. Although management styles will vary according to the situation, consistency of an administrator's actions and approaches is desirable for stability. Maurice P. Marchant has indicated that "service is better in libraries that involve the staff in their management than in libraries run by authoritarian methods. Staff client relations and reference service are strongly affected, and the quality of other services and collection development are also modified by management style." ${ }^{\prime \prime}$ Marchant also states that there is evidence that improved accuracy of upward communication from staff provides management with better information with which to act and plan.?

\section{"Fear is the worst element that can be unleashed in an organization."}

Fear is the worst element that can be unleashed in an organization. It can cause job dissatisfaction and bring the achievements of an organization to a standstill. An administrator must inspire trust. As Marchant observes, "the staff's judgment of the confidence and trust their leaders have in them is the most important aspect of participative management. ${ }^{18}$ Although there are many styles of management, this author believes that one of the most effective is participative management. Still, this style may only be used up to a point, for there are times when a group cannot make a decision and an administrator must. For stability's sake and for the quality of leadership that most librarians wish to see in their administrators, the director must clearly show where participative management leaves off and administrative leadership begins. In the course of providing leadership, an administrator should not penalize a librarian who may disagree with him or her.

Louis Kaplan notes that a study by Frank A. Heller identified several organizational factors that influence decision sharing. 
1. If the decision is perceived to be of great importance to the organization, the superior is likely to use a one-sided style.

2 . If the decision is perceived to be important to the subordinate, the senior will likely use a less autocratic style.

3. If the decision is believed to be of greater significance to the senior than to the subordinate a one-sided decision is likely to be made.

4. The greater the senior's "span" of control the more likely that a time-saving style will be employed that is autocratic or delegative. ${ }^{9}$

These factors presuppose that in many instances the decision will have little or no affect on the subordinate; however, in a library setting, the decisions made usually affect those working within the structure. The question is usually to what degree decisions will affect professional librarians. Even though an administrator may feel that no input is necessary from subordinates in a given situation, it is still advisable to seek input. This will encourage communication and have a positive effect on employee-employer relationships.

Personnel factors, of course, do shape the making of decisions. Kaplan notes that American managers have less confidence in the skills of subordinates than do English managers. ${ }^{10}$ If a director believes subordinates lack certain skills, it is natural for that director to prefer an authoritarian style. Unfortunately this attitude does not allow for the development of skills that may exist or new ideas that would strengthen a library organization in the long run. The benefits of autocracy are short term and dependent on the skill of the administrator alone. The danger exists that once an autocratic style is in place there is little reason for a subordinate to mention problems that may result from decisions. Peter F. Drucker states that in organizational structures where dissent is permitted and even encouraged groups are better able to adapt to changing needs and conditions. ${ }^{11}$ Kenneth Plate and Elizabeth Stone, in their assessment of the dangers of autocratic administration, classify it with low salaries and wretched working conditions as producing employee dissatisfaction. ${ }^{12}$
The administrator may not be aware that a failure to delegate can sometimes be interpreted by the subordinate as both lack of trust and support. One of the reasons cited for librarian burnout is lack of supervisory support. ${ }^{13}$ Others include incompetent administration, work overload, and verbal abuse. ${ }^{14}$ This situation leads to a loss of self-esteem and consequently a feeling that there is no prestige in the assigned work. There are several types of prestige in librarianship, e.g., prestige built on library collections and on a dynamic, innovative, and cooperative faculty. The latter can lead to achievements and breakthroughs within the profession. The former is an asset to research but if not followed by the second quality the danger exists that prestige may be limited to collections and may not include personnel. Personnel involvement helps build satisfaction and personal prestige. ${ }^{15}$

Another element of personnel involvement is the Japanese approach to management. The Japanese do not focus on giving an answer but rather on defining a question. ${ }^{16}$ This approach assures involvement, hence, adding to prestige. After defining the question, the analysis of the problem and possible solutions to it are natural extensions. Plate and Stone also point out that achievement and recognition (prestige) appear to be most important in job satisfaction. ${ }^{17}$

The next element that a librarian expects is a salary that reflects the professional nature of the employment. The field is dominated by women: in 1979 librarians numbered 188,000 , with 80.9 percent being women. ${ }^{18}$ Bettina Berch refers to the lowpay characteristic of female-dominated professions as a pink-collar ghetto. ${ }^{19}$ In an effort to deal with this situation librarians in some areas are turning to the doctrine of comparable worth. Under this doctrine, discrimination exists when workers of one sex, race, or ethnicity are paid less than workers in a totally different category although their comparable worth is the same. ${ }^{20}$ Theoretically, this doctrine can be applied to the entire library profession and not just to instances involving low pay for female employees. In dealing with the predisposition of university employ- 
ers to underpay librarians the library administrator is in an unenviable position. Library personnel, however, would expect an administrator to fight to upgrade their employment conditions and salaries. Staff advancement opportunities via professional growth, promotion, and salary increases are necessities. ${ }^{21}$ As Maurice P. Marchant states, "The individual librarian must be able to recognize a personal payoff available for good performance."

A healthful and comfortable environment is important because this influences the contributions a person makes to an organization. ${ }^{23}$ It is also essential to good health and job satisfaction. If a librarian has no privacy, this will affect the work product. The librarians may become irritable and show signs of burnout. Creativity will plummet. Sick leave may increase. Improper lighting, inadequate support personnel, and crowded working conditions may all have an adverse affect on performance. Architecturally it may not be feasible to provide personal offices for each librarian; however, if offices are available, the limit for sharing space should be two people to an office. In common work areas, an effort should be made to give an appearance of privacy. Privacy is important psychologically and is a vital element for efficient, creative academic librarianship.

The qualities that librarians expect in a position are not unreasonable. The qualities the librarian would expect from an ad-

\section{"The qualities the librarian would expect from an administrator revolve around three separate areas- direction, security, and environ- ment."}

\begin{abstract}
ministrator revolve around three separate areas-direction, security, and environment. In the realm of direction, a librarian should expect leadership, clear administrative lines, and flexibility. In the area of security the librarian should expect stability, a proper job description, support from administration, and a professional salary. From the environment of the position the librarian should expect responsibility, meaning, prestige, growth opportunities, support services, and a healthful working condition. Having these factors available makes it possible for a librarian to do a better job. In the $1980 \mathrm{~s}$, with the profession groping to meet the requirements being placed upon it by administrators, the employee is justified in asking that same administration to provide an environment conducive to meeting organizational demands. Good management is a team effort: the administrator needs competent, creative employees and the employees need competent leaders who provide direction, security, and an environment that promotes achievement.
\end{abstract}

\section{REFERENCES}

1. Betty Ann Stead and Richard W. Scannell, "A Study of the Relationship of Role Conflict, the Need for Role Clarity and Job Satisfaction for Professional Librarians," Library Quarterly 50, no.3:310-23 (July 1980).

2. Walter S. Nord, "Job Satisfaction Reconsidered," American Psychologist 32, no.12:1026-35 (Dec. 1977).

3. Alan L. Frohman, "Mismatch Problems in Managing Professionals," Research Management 21, no. 5:20-25 (Dec. 1978).

4. Ibid., p. 24 .

5. Ibid.

6. Maurice P. Marchant, "Participative Management, Job Satisfaction, and Service," Library Journal 107:782-84 (Apr. 15, 1982).

7. Ibid., p.783.

8. Ibid.

9. Louis Kaplan, "On Decision Sharing in Libraries: How Much Do We Know? College \& Research Libraries 38:25-31 (Jan. 1977). 
10. Ibid., p. 28 .

11. Robert S. Runyon, "Some Principles of Effective Decision Making in Academic Libraries," Journal of Academic Librarianship 8, no.3:144-50 (July 1982).

12. Kenneth H. Plate and Elizabeth W. Stone, "Factors Affecting Librarians' Job Satisfaction: A Report of Two Studies," Library Quarterly 44:97-110 (Apr. 1974).

13. Rudolph Bold, "Librarian Burnout," Library Journal 107:2048-51 (Nov. 1, 1982).

14. Ibid., p.2049.

15. Frohman, "Mismatch Problems in Managing Professionals," p.25.

16. Runyon, "Some Principles of Effective Decision Making in Academic Libraries," p.146.

17. Plate and Stone, "Factors Affecting Librarians' Job Satisfaction: A Report of Two Studies," p.107.

18. Bettina Berch, The Endless Day: The Political Economy of Women and Work (New York: HBJ, 1982), p.72.

19. Ibid., p.75.

20. "The Comparable Worth Issue: A BNA Special Report," Fair Employment Practice Manual, supplement 433, part 2 (Nov. 7, 1981), p.1.

21. Marchant, "Participative Management, Job Satisfaction and Service," p.784.

22. Ibid.

23. Herbert G. Hicks and C. Ray Gullet, The Management of Organizations, 3d ed. (New York: McGrawHill, 1976), p.64. 